\title{
Examining of Organizational Citizenship Behaviors and Employee Involvement in Transformational Leadership and Organization Support: A Research on White Collar Bank Employees
}

\author{
Fatma SÖNMEZ ÇAKIR iD a Zafer ADIGÜZEL (iD b \\ a Bartin University, Faculty of Economics and Administrative Sciences, Bartin, Turkey. fsonmez@bartin.edu.tr \\ b Istanbul Medipol University, Medipol Business School, Istanbul, Turkey. zadiguzel@medipol.edu.tr
}

\begin{tabular}{|c|c|}
\hline ARTICLE INFO & ABSTRACT \\
\hline $\begin{array}{l}\text { Keywords: } \\
\text { Transformational Leadership } \\
\text { Organizational Support } \\
\text { Organizational Citizenship } \\
\text { Behaviors } \\
\text { Employee İnvolvement } \\
\text { PLS-SEM }\end{array}$ & $\begin{array}{l}\text { Purpose - The survival and growth of a business in the 21st century depends on its ability to create } \\
\text { and maintain a competitive advantage. In particular, the ability to create a sustainable competitive } \\
\text { advantage enables an enterprise to maintain and improve its competitive position in the market. } \\
\text { This can also be achieved through the management style and employees. Nowadays, it is not } \\
\text { possible to obtain efficiency from the educated workforce that has become qualified. The self- } \\
\text { sacrificing, self-fulfilling, self-sacrificing workforce works more efficiently than the labor force, } \\
\text { which obeys orders only under the supervision of the tasks assigned to them. Therefore, the research } \\
\text { aimed to determine the effects of the relations between organizational citizenship behavior and } \\
\text { employee involvement with the variable effect of the organizational support tool of transformational } \\
\text { leadership. }\end{array}$ \\
\hline $\begin{array}{l}\text { Received } 2 \text { January } 2020 \\
\text { Revised } 7 \text { March } 2020 \\
\text { Accepted } 11 \text { March } 2020\end{array}$ & $\begin{array}{l}\text { Design/methodology/approach - SmartPLS } 3.2 \text { program was used for factor analysis of surveys } \\
\text { collected for this purpose, Partial Least Square Structural Equation Model (PLS-SEM) Path analysis } \\
\text { and Mediation effect analysis. In this research, } 398 \text { white collar employees working in the service } \\
\text { sector constitute the sample group. }\end{array}$ \\
\hline $\begin{array}{l}\text { Article Classification: } \\
\text { Research Article }\end{array}$ & $\begin{array}{l}\text { Findings - Transformational leadership and organizational support had positive effects on } \\
\text { employee participation and organizational citizenship behaviors, and mediation effect of } \\
\text { organizational support was revealed as a result of the analyzes. }\end{array}$ \\
\hline & $\begin{array}{l}\text { Discussion - Organizational citizenship behavior (OCB) is referred to as optional workplace } \\
\text { behavior that exceeds the basic business needs of employees. These behaviors are often described as } \\
\text { behaviors other than those that need to be done in the act. OCB has been the subject of extensive } \\
\text { research since it was first introduced almost thirty years ago. According to the results of the research, } \\
\text { rotating leadership and organizational support positively affect organizational citizenship behavior. } \\
\text { OCB was also seen as "close and supportive" behavior that reflects the willingness of the employees } \\
\text { who exhibited the behavior to maintain their relationship with their colleagues or the organization } \\
\text { itself and contribute to the success of the target. Therefore, it is possible for employees in } \\
\text { organizations that feel the support of the organization and whose leadership style is appropriate to } \\
\text { feel belonging to the organization and to consider themselves as one of the organization. }\end{array}$ \\
\hline
\end{tabular}

\section{Introduction}

The difference in the vision structures of the leaders fires the wick of the motivation source they need in the followers and helps to identify with the leader. Employees in an organization can be named as followers, led or managed. The aim of leaders is to understand the values and hopes of their followers and to enable them to change their attitudes and behaviors positively towards the aims of the organization (Shamir \& Howell, 1999). Those who are managed within the organization have confidence, admiration, commitment and respect for their leaders, and are motivated to work harder than their will and perform high outside their roles (Barbuto, 2005). The performance of the leaders for the transformational leaders within the window drawn in their job descriptions, the service they provide to the organization in this limited area, the extra role or organizational role that employees undertake in line with the interests of the organization not as important as citizenship behavior (Podsakoff et al., 1990). Employees led by a transformative leader are motivated to do much more than they normally envision. Because they feel the respect, trust and loyalty of the transformative leader towards their leaders (Washington, 2007). In terms of organizations, it is seen as advantageous for Önerilen Atıf/Suggested Citation

Sönmez Çakır, F., Adıgüzel, Z. (2020). Examining of Organizational Citizenship Behaviors and Employee Involvement in Transformational Leadership and Organization Support: A Research on White Collar Bank Employees, Journal of Business Research-Turk, $12(1), 111-125$. 


\section{F. Sönmez Çakır - Z. Adıgüzel 12/1 (2020) 111-125}

employees to participate in decisions and to actively participate in organizational activities. However, in the event that employees are involved in decisions concerning the organization, it is not always right to ask for employees' participation in management, considering the possibility that activities will slow down. Another issue in the participation of employees in decisions concerning the organization is the disagreement caused by the failure of management and employees to meet the common denominator. In order to prevent this negative situation, the organization's administrations are engaged in activities aimed at ensuring that employees are on their side by providing support and motivation on the employees (Nam, 2003). It is emphasized that in order to eliminate the conflict between management and employees, it is emphasized that they should be involved by giving the employees authority and responsibility, but not to make sure that this authority and responsibility becomes a force (Apostolou, 2000). Discussions are ongoing regarding the full definition of organizational citizenship behavior (OCB) or the functioning of this concept. This is partly due to the fact that most of the OCB research focuses on understanding the relationship between the OCB and other concepts, rather than trying to define the structure itself carefully. However, one of the distinguishing features is that the supervisors do not require or force employees under their command to take the OCB. Similarly, it is not possible for employees to expect any official reward in return for their discretionary behavior. In particular, the important claim put forward by the Organ (1988) on the basis of the OCB is that the motivation of organizational citizenship behaviors is often the employees themselves, that is, the behaviors that are nurtured by the need to feel the sense of accomplishment, competence, belonging or closeness within the employees. The participation of employees can be defined as an empowering effect on organizations. In particular, it can be seen that there are positive effects on the performance of the organization as a result of the sincere and willing participation of the employees in the activities of the organization. In achieving this positive impact, leadership role and organizational support play an important role in achieving this positive impact. Therefore, within the scope of the research, the effects of transformational leadership and organizational support on employee participation and organizational citizenship behavior are examined.

\section{Literatur}

\subsection{Transformational Leadership}

Transformational leadership was first introduced by Burns (1978) and then by Bass (1990), the scope and depth was expanded under this concept by combining the features of giving importance to the future, being in favor of innovation and being reformist (Eren, 1998). Podsakoff et al. (1990) discussed the need to adopt it as an effective form of leadership by evaluating the transformational leadership approach in new dimensions since its inception; this type of leadership has an effect on the performance of the employees beyond the expected and they have an active role in the role behaviors of the employees. Leaders who incorporate the qualities of transformational leadership exhibit a number of basic behaviors in which they can directly influence the group. These are briefly; idealized impact, inspiring motivation, intellectual stimulation and individual support (Bass, 1990). Transformative Leadership is an attractive theory that gives insight into leadership differences and provides a model for the development of leadership (Tucker \& Russell, 2004). Transformational leadership is defined as a process that motivates people by addressing higher ideals, moral values, and by expressing and defining the vision of the future, and by building the foundation of credibility (Eisenbeiss et al., 2008). Transformational leaders affect the employees in the extraordinary situations of the organization and also in times of crisis, ensure their loyalty to the organization, and help to develop new perspectives and find new solutions to the problems encountered (Yavuz, 2009). In other words, from a longterm perspective, the transformational leader not only creates a positive change in his followers, but also supports his followers to play an active role in non-routine problems. The transformational leader inspires his followers and motivates them to work harder to achieve successful results with his ideas (Bass, 1990). It adds value and meaning to their work in order to motivate employees (Akyurt et al., 2015). It inspires the team spirit of inspiring leader followers, motivates them to solve the problems they face and to be more successful in their work (Hemedoğlu \& Evliyaoğlu, 2012). The effect of the research model on rotating leadership in providing organizational support as well as its effects on organizational citizenship behavior and employee involvement are examined. Hypotheses developed and tested within this scope;

H3: TL has a positive effect on EI in organizations

H4: In organizations, TL has a positive effect on OCB

H5: In organizations, TL has a positive effect on OS 


\subsection{Organization Support}

Organizational support is the general beliefs of the employees towards the organization and their perceptions of caring for the well-being of the employees according to the value of their efforts and the importance of their happiness (Eisenberger et al., 1986). Some employees base organizational support on factors such as the organization's ability to help them to complete a job or provide them with tools, while others assess the support provided by members of the organization (Addae et al., 2017). This concept, which emerged in the mid-1990s, attracts the attention of researchers working in psychology and management. One of the reasons for the recent increase in interest in the perceived concept of organizational support is the restructuring and downsizing (Aube et al., 2007), which occurs during times of crisis, especially in many organizations in America and Europe. Organizational support is an expression of the interest in the needs of the employees of the organizations. Organizations support their employees as they want to increase their work-related efforts and have a positive overview of their work. They meet and support their socio-emotional needs (Imam \& Javed, 2019). Among the most important socio-emotional needs of employees are salary, health care, and gaining respect in society. In other words, organizations support them by motivating their employees with their human resources strategies (London, 1988). Organizational support is influenced by the relationship between managers and employees and the behaviour of employees (Johlke et al. 2002). It explains the relationship between employees and the organization. Here, the interaction of both sides, i.e. the employee and the organization, is important. Because perceptions and expectations on both sides vary according to the behavior of the other side (DeConinck \& Johnson, 2009). Therefore, the support of the organization will change in line with the experience of the employees (Erdogan et al., 2004). Organizations must create a motivating and supportive environment for their employees to realize their dreams (Antoncic \& Hisrich, 2001). It is inevitable that organizations will consider and value their employees as internal customers in order to succeed (Yang, 2010). Within the scope of this scope, the phenomenon analyzed in the study is the mediation effect of organizational support between rotating leadership and organizational citizenship behavior and transformational leadership and employee participation. For this purpose, the following hypotheses have been established.

H6: In organizations, the OS variable has a mediator effect on the relationship between TL and OCB.

H7: In organizations, the OS variable has a mediator effect on the relationship between TL and EI.

\subsection{Employee Involvement}

Various definitions have been made regarding employee participation in the literature. Employee participation is the ability of employees to participate in organizational activities, to benefit from the skills of the employees through motivation, and to take part in processes and procedures (Cotton, 1993). It is called employee participation in the organization's administrations to engage in activities that contribute to the development of the organization by ensuring the participation of employees in the processes (Apostolou, 2000). In order to achieve efficient results, employees need to be supported by the management of organizations, as well as to understand the employees and manage the process well (Osterman, 2000). This shows how important the welfare of the workers within the organization is. It is more possible to achieve the goals and objectives set by ensuring employee participation both in terms of leadership style and organizational support. Interesting highlights are made in the researches on employee participation. In particular, there are explanations in organizations as motivating and inclusion of employees who are not fully productive and who have not been given any duties or responsibilities (Locke \& Schweiger, 1979; Wagner, 1994). In terms of today's conditions, it is very difficult for white collar (qualified employees) to support this definition. Because it does not idle a qualified white collar employee within any organization or it does not contain it without any duties or responsibilities. This explanation may only apply to blue-collar people with certain exceptions. The most important goal in ensuring employee participation lies in making the employees feel that they belong to the organization. Employees are considered to be the most valuable assets of organizations. Continuous improvement can be achieved as a result of the information of employees reflected to the organization as new ideas and ideas (Marchington et al., 2005). Newman and Griggs (2008) concluded that employee participation always increases employee performance and motivation and reduces stress. Moreover, employee engagement helps to improve the performance of the organization as a whole. Apostolou (2000) requires organizations to take a number of steps to encourage employee participation practices, 


\section{F. Sönmez Çakır - Z. Adıgüzel 12/1 (2020) 111-125}

organizations provide adequate training for their employees, establish appropriate communication channels between management and employees, and feedback they need to improve. In this, the importance of leadership style and organizational support emerges. Hypotheses developed and tested within this scope;

H1: OS has a positive impact on EI in organizations

\subsection{Organizational Citizenship Behaviors}

Change and competition, taking the human resource that constitutes the lowest part of the organization pyramid in the past, has moved to the highest points of the organizational pyramid in creating organizational vision and providing organizational efficiency and productivity today (İnce, 2005). Businesses know the capacity of the machines they have, so they can estimate how much they can produce per day. However, human resources, whose capacity cannot be fully estimated, can perform differently under different conditions. For this reason, human resources have become the most important production factor for businesses today. Many business executives and scientists acknowledge that the main source of competitive advantage is the personnel of the enterprise and that all personnel should be involved in order to succeed (Çavuş \& Akgemci, 2008). Businesses that seize qualified human resources and use it efficiently gain a significant advantage in the competition race (Ögüt et al., 2004). According to Katz (1964), organizations must respect three issues in order to be successful. The first is that employees arrive on time, secondly employees perform the tasks specified in their contracts in a complete, timely and desired manner, and the third is that the employees operate in favor of the organization and volunteer in this regard. They are in order to ensure that employees meet and show solidarity with one another, defend their organizations in the face of accusations made inside and outside, to ensure quality and efficiency, except for timely employment and performing the tasks given. They need to support change, share business information with one another, and strive to provide a peaceful environment. Organizational citizenship of the businessman who spontaneously performs the tasks assigned to them and more without waiting for compensation, who works hard to create a peaceful business environment, who values the organization to which he belongs and who feels of a bond of heart, behaviors (Torun, 2010). In the organizational sense, civic behavior plays an accelerating role in the completion of tasks that are expected to be performed by the employees in an organizational, social and psychological context beyond business performance and technical competence. Today, people spend most of their lives in organizations and use organizations as tools to achieve their individual goals. When individual objectives and organizational objectives are combined with a common denominator, creative energy will emerge and organizations will be able to function in a healthier way (Gürsel \& Negiş, 2008). Hypotheses developed and tested within this scope;

\section{H2: OS has a positive influence on the OCB in organizations}

\section{Methodology}

The SmartPLS 3.2 program was used for factor, PLS-SEM Path and Mediation effect analysis of surveys collected from 398 white-collar employees as part of the study. In the study, the white collars working in banks constitute the sample mass. The aim of the study is to reveal the positive effect of transformation leadership on organization support, employee involvement and organizational citizenship behaviors according to the research model given in figure 1 , as well as to reveal the mediation effect between transformation leadershiporganizational citizenship behaviors and transformation leadership-employee involvement. In this study, the service sector (banks) was preferred because employment also had an important share. Employees in this sector can do more activities in favor of their institutions other than the work given to them. This flexibility is not very achieved in manufacturing enterprises. For this reason, the service sector constituted the main mass. The questionnaire consists of 4 variables. In the literature studies for the Transformational Leadership Scale, scales developed by Li et al. (2013), Wang et al. (2013), which are referenced in many studies, were utilized. In measuring the organizational support variable; The scale developed by Eisenberger et al. (1986), Hellman et al. (2006) was used. Organizational citizenship behaviors scale was used by scales developed by Podsakoff et al. (1990), Podsakoff et al. (2006), Moorman (1991). For the employee involvement scale; the scale developed by Rangus et al. (2016), Rangus and Slavec (2017), was used. In order to avoid the common method variance problem, the scale was made according to the rules of anonymity, the number of questions was kept low and the respondents were given enough time. A preliminary test of 60 people was conducted before the full use of the scale was carried out, and the scale was rearranged because some expressions were not understood. In 


\section{F. Sönmez Çakır - Z. Adıgüzel 12/1 (2020) 111-125}

expressions that measure variables on the scale, 4 factor loads are removed from the scale because they are below 0.40. The Cronbach Alpha coefficient was 0.902 for a scale of 26 expressions used after the implementation of the healthy questionnaire. The banking sector was selected to narrow the main mass of the study. This sector is one of the leading organizations in the service sector and has been considered very suitable for work because of the multi-customer and multi-transactions. The survey was conducted on white-collar people in the administrative departments of banks in the service sector. 398 white-collar employees working in different departments answered the questionnaire in accordance with the criteria. 398 people are sufficient size for the main mass size and 5\% significance level (Yazıcığlu \& Erdoğan, 2004). 212 (186\%) males and 108 (31\%) females answered the questionnaire. While $330(40 \%)$ of the respondents were university graduates, 18 (13\%) had masters degree.

The SEM model for Path analysis has been established in the application section. SEM Models can be shown in two titles: Kovaryans Based SEM (CB-SEM) and Partial Least Square SEM (PLS-SEM). It is widely used in many areas where multivariate statistical methods are used (Kock \& Hadaya, 2018). Wold (1975), a Swedish econometrician, laid the statistical foundation for the PLS-SEM method. The model is seen as an alternative to Jöreskog's (1970) Covariance-based SEM (Hair et al., 2019). Although it has a wide range of uses, a limited number of applications are encountered when the literature is examined, but the number of applications is increasing day by day (Sharma et al., 2019). Considering other SEM structures, pls-SEM advantages are considerable. The highlight of PLS-SEM is that the method allows researchers to predict many structures, indicator variables and structural pathways and complex models without applying distribution assumptions on data (Hair et al., 2019). The reason for using PLS-SEM in this study is that the prediction of the dependent variable is focused. The data size is suitable for both CB-SEM and PLS-SEM. PLS-SEM can be used easily in cases where both formative and reflective structures are present at the same time in the working model. At the same time, there has been a strong increase in the analysis conducted with PLS-SEM in recent years. It is aimed to make another application for PLS-SEM which is used in many fields. Application results and reviews are given in the Analysis section.

\subsection{Research Framework}

In this study, data were analyzed to explain the relationships between statistical concepts because a quantitative approach was adopted. In a quantitative approach, the data obtained to judge the effect of the argument on the dependent variable in the relationships between variables are analyzed and hypotheses determined within the research model are tested (Thomas et al., 2015).

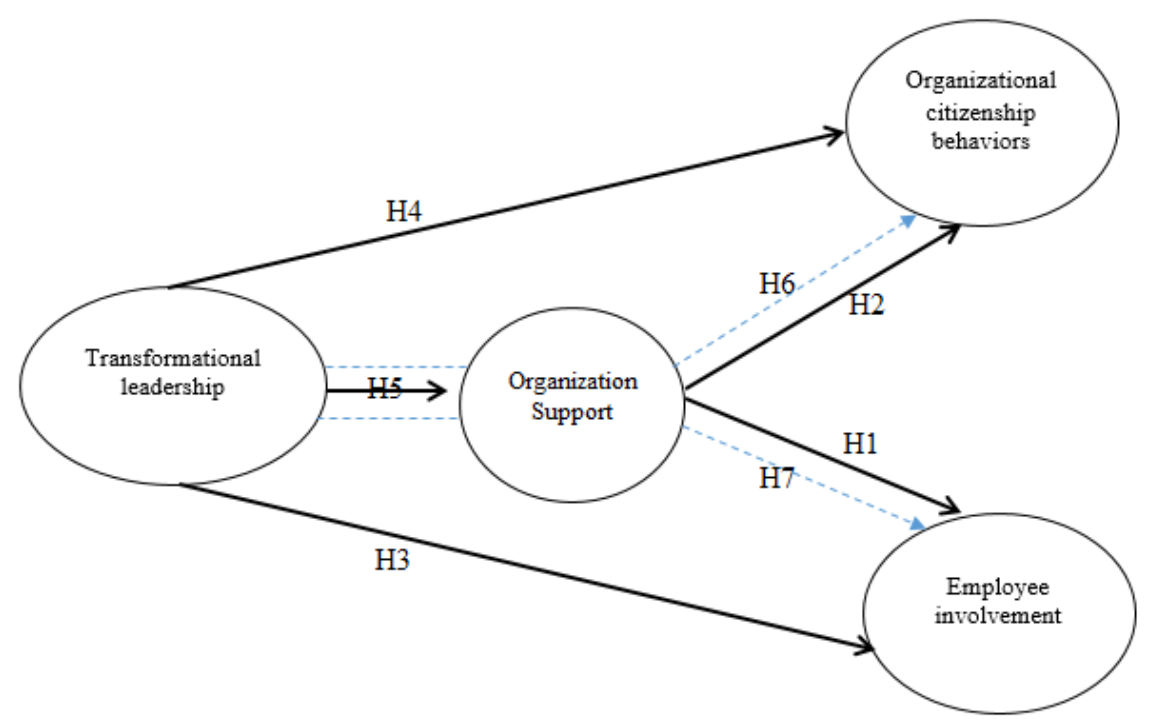

Figure 1. Research Model

\subsection{Analysis}

Factor analysis was used to test the structural validity of the scale. Factor analysis of the data obtained, PLSSEM Path Analysis analysis and mediator effect analysis were performed in SmartPLS 3.2 program. Using 
PLS-SEM, the following Fig. The inner model given in 2nd has been tested. Reflective model structure? Or is it formative? Confirmatory Tetrad Analysis was performed after being subjected to data factor analysis to determine the nature of the data factor. All CI low and CI up values have been observed in comparable $(-,+)$ structures and the model has been proven to be a reflective model. Analyses and interpretations are given on reflective model structure. The model definition is made as shown in the Inner model so that the arrows drawn between the variables and the variables in the model do not mix.

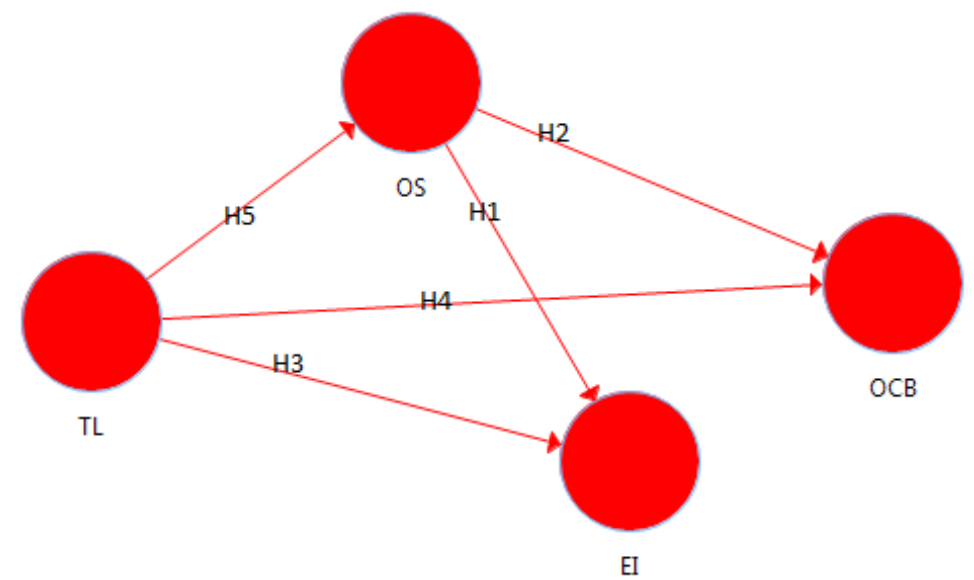

Figure 2. Inner Model for PLS-SEM Path Analysis

Figure 2 shows four variables. Arrows between variables provide information about the direction of the relationship. In this case, the model was primarily used to test the five hypotheses on it.

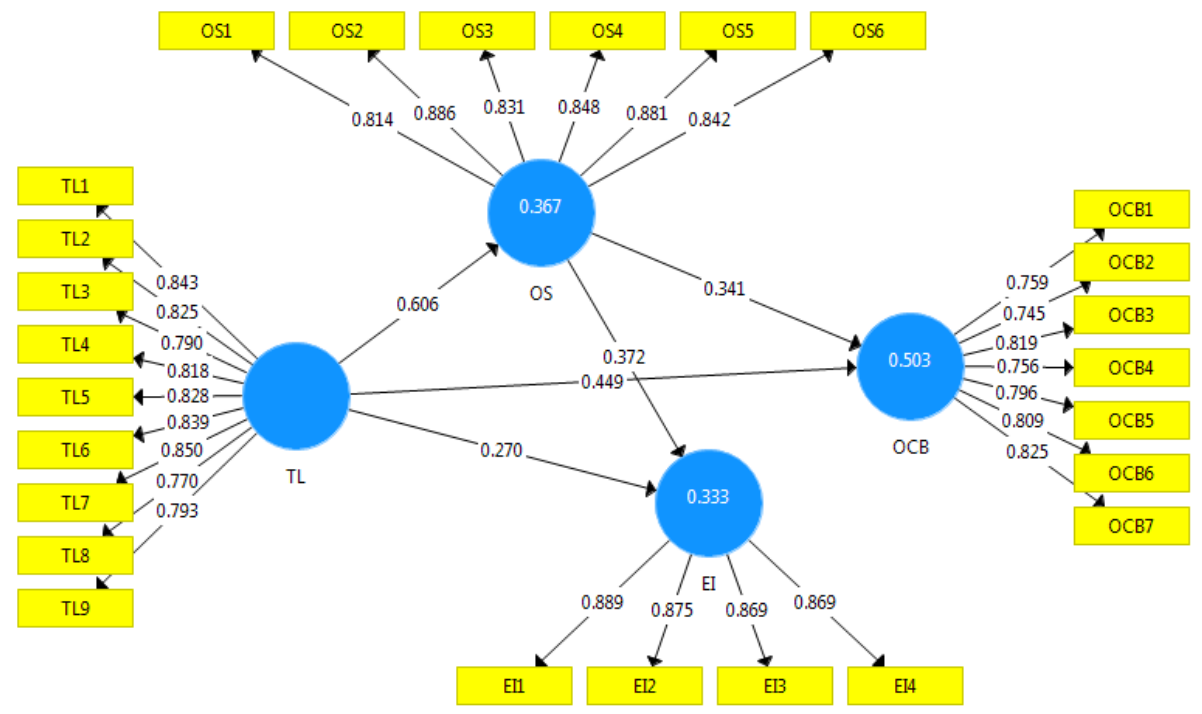

Figure 3. Outer Model for PLS-SEM Path Analysis

Figure 3. the outer model of the data. The four specified factors are composed of expressions given in the figure. Figure 3. three basic results are shown. These are R2 values between factor loads, path coefficients, and hidden variables. The values written on the arrows between the factors and the expressions indicate factor loads. The values in the arrows between the four factors give the road coefficients. The values written in factor rounds are $\mathrm{R} 2$ values.

Outer loadings determines indicator reliability value. When the squares of these loads are taken, the indicator reliability value is obtained. Factor loads over $70 \%$ are preferred, and if an explanatory analysis is performed, more than $40 \%$ is acceptable (Hulland, 1999). Table 1. the factor loads of all expressions are over $70 \%$.

It can be seen that all of the indicators have individual indicator reliability values that much larger than the minimum acceptable level of 0.4 (Wong, 2019). Reliability coefficient; it is defined as the intrinsic consistency of the measurement that takes into account the average relationship between questions. The Cronbach Alpha 
F. Sönmez Çakır - Z. Adıgüzel 12/1 (2020) 111-125

coefficient gives this intrinsic consistency. Measurements with a coefficient of 0.50 or higher are considered sufficient (Nunnally, 1978; Hair et al., 2011).

Table 1. Model Factor Analysis Results

\begin{tabular}{|c|c|c|c|c|c|c|c|c|c|c|}
\hline $\begin{array}{c}\text { Latent } \\
\text { Variable }\end{array}$ & Indicators & Loadings & $\begin{array}{l}\text { Indicator } \\
\text { Reliabilty }\end{array}$ & $\begin{array}{c}\text { Cronba } \\
\text { ch's } \\
\text { Alpha }\end{array}$ & rho_A & $\begin{array}{l}\text { Composite } \\
\text { Reliability }\end{array}$ & (AVE) & $\begin{array}{c}\mathbf{R} \\
\text { Squ } \\
\text { are } \\
\end{array}$ & $\begin{array}{c}T \\
\text { Statis. }\end{array}$ & VIF \\
\hline \multirow{4}{*}{ 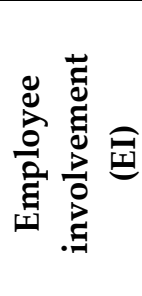 } & EI1 & 0.889 & 0.790 & \multirow{4}{*}{0.899} & \multirow{4}{*}{0.904} & \multirow{4}{*}{0.929} & \multirow{4}{*}{0.766} & \multirow{4}{*}{$\begin{array}{l}0.33 \\
3\end{array}$} & 18.865 & 2.908 \\
\hline & EI2 & 0.875 & 0.766 & & & & & & 14.452 & 2.871 \\
\hline & EI3 & 0.868 & 0.753 & & & & & & 16.932 & 2.275 \\
\hline & EI4 & 0.869 & 0.755 & & & & & & 13.346 & 2.471 \\
\hline \multirow{7}{*}{ 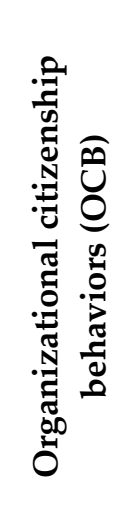 } & OCB1 & 0.759 & 0.576 & \multirow{7}{*}{0.898} & \multirow{7}{*}{0.902} & \multirow{7}{*}{0.920} & \multirow{7}{*}{0.621} & \multirow{7}{*}{$\begin{array}{l}0.50 \\
3\end{array}$} & 14.151 & 1.800 \\
\hline & OCB2 & 0.745 & 0.555 & & & & & & 12.687 & 1.886 \\
\hline & OCB3 & 0.819 & 0.671 & & & & & & 15.720 & 2.247 \\
\hline & OCB4 & 0.756 & 0.571 & & & & & & \begin{tabular}{|l|}
15.250 \\
\end{tabular} & 2.188 \\
\hline & OCB5 & 0.796 & 0.634 & & & & & & 13.895 & 1.924 \\
\hline & OCB6 & 0.809 & 0.654 & & & & & & 16.475 & 2.474 \\
\hline & OCB7 & 0.825 & 0.681 & & & & & & 15.398 & 2.288 \\
\hline \multirow{6}{*}{ 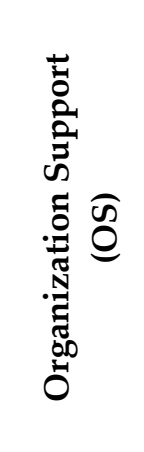 } & OS1 & 0.814 & 0.667 & \multirow{6}{*}{0.923} & \multirow{6}{*}{0.924} & \multirow{6}{*}{0.940} & \multirow{6}{*}{0.724} & \multirow{6}{*}{$\begin{array}{l}0.36 \\
7\end{array}$} & 16.755 & 2.145 \\
\hline & OS2 & 0.886 & 0.785 & & & & & & \begin{tabular}{|l|}
19.870 \\
\end{tabular} & 3.444 \\
\hline & OS3 & 0.831 & 0.691 & & & & & & 19.599 & 2.654 \\
\hline & OS4 & 0.848 & 0.719 & & & & & & 16.836 & 2.814 \\
\hline & OS5 & 0.881 & 0.776 & & & & & & 21.787 & 3.129 \\
\hline & OS6 & 0.842 & 0.709 & & & & & & 21.039 & 2.637 \\
\hline \multirow{9}{*}{ 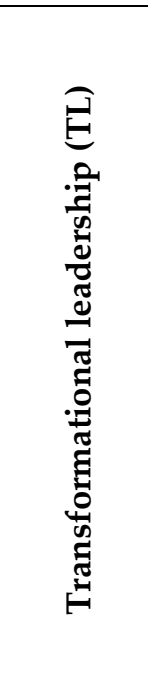 } & TL1 & 0.843 & 0.710 & \multirow{9}{*}{0.938} & \multirow{9}{*}{0.939} & \multirow{9}{*}{0.948} & \multirow{9}{*}{0.669} & \multirow{9}{*}{ - } & 15.754 & 2.850 \\
\hline & TL2 & 0.825 & 0.688 & & & & & & 21.625 & 2.753 \\
\hline & TL3 & 0.790 & 0.681 & & & & & & 19.670 & 2.231 \\
\hline & TL4 & 0.818 & 0.669 & & & & & & 19.729 & 2.487 \\
\hline & TL5 & 0.828 & 0.686 & & & & & & 17.509 & 2.737 \\
\hline & TL6 & 0.839 & 0.704 & & & & & & 21.720 & 3.231 \\
\hline & TL7 & 0.850 & 0.723 & & & & & & 17.394 & 3.313 \\
\hline & TL8 & 0.770 & 0.593 & & & & & & 17.877 & 2.156 \\
\hline & TL9 & 0.793 & 0.629 & & & & & & 20.455 & 2.380 \\
\hline
\end{tabular}

The resulting Cronbach's Alpha reliability coefficients are table 1. is also given. When the values are examined, it can be seen that all Alpha values are above 0.85. Composite Reliability should be above 0.70 for model reliability. Table 1. all Composite Reliability values are over 0.70. AVE (Average Variance Extracted) gives the value of the validity of the match (Convergent validity). In order for the validity of the match to be properly 


\section{F. Sönmez Çakır - Z. Adıgüzel 12/1 (2020) 111-125}

defended in the model, this value must be 0.50 or higher (Bagozzi \& Yi, 1988; Alarcón et al., 2015). Dijkstra and Henseler (2015) also used and interpreted the coefficient of rho_A. the Rho_A coefficient is a coefficient that provides better estimation of data consistency and the results show whether factor elements are reliable and are a very important safety measure for PLS (Ringle et al., 2018). Dijkstra and Henseler (2015)'s rho (rhoA) coefficient was used to ensure more accurate estimation of data consistency, and values show that items loaded in each structure are reliable (Ringle et al., 2018). It is preferred that the RHO value is above 0.70 . The R Square value shows how much variables explain each other, and if it is greater than 0.26 , the variable affects the other largely (Cohen, 2013). $T$ test results are given because all expressions are meaningful or not. All $t$ values are greater than 1.96 and indicate that these expressions are statistically significant for the model. Whether there is a multi-link problem between multiple variable expressions in the model can be looked at with VIF values and VIF value that exceeds 10 is an indication of severe multicollinearity (Neter et al., 1996). VIF values are lower than 5 indicate that there is no problem of multicollinearity (Hair et al., 2011). Table 1. all of the VIF values given have VIF scores below the reference value. There is no multicollinearity problem in the data. As you can see, all situations are suitable for factor analysis. All values obtained from the data set are recorded in reference ranges. Path analysis applications were made in the next stage.

Discriminant validity is one of the most interpreted values in PLS-SEM analysis. When interpreting this value, all the values in the rows and columns are looked at. If a hidden variable (Latent Variable) is compared with itself, the resulting discriminatory value must be greater than all values in the same column and on the same line of the table (Fornell \& Larcker, 1981). This is called the Fornell-Larcker criterion and shows how the factors differ from each other and how they represent the model. The AVE value can be assessed by comparing the amount of variance of the entire structure and the amount of variance shared with other structures. The square root of the AVE value must be greater than the variance value shared with other structures (Alarcón et al., 2015). Table 2 shows these values. Table 2. When the Discriminant Validity column is examined, all values shown in dark color (For example (EI) Discriminant Value =) are the largest values in the row and column in which they are located. According to the given criteria, the model has the validity of the decomposition.

Table 2. Latent Variables Correlation, Discriminant Validity and Fit Index

\begin{tabular}{|l|l|l|l|l|l|l|l|l|l|l|l|}
\hline & \multicolumn{4}{|c|}{ Correlations } & \multicolumn{3}{c|}{$\begin{array}{c}\text { Discriminant Validity } \\
\text { (Fornell-Larcker Criterion) }\end{array}$} & \multicolumn{5}{c|}{$\begin{array}{c}\text { Heterotrait-Monotrait (HTMT) } \\
\text { Ratios }\end{array}$} \\
\hline & EI & OCB & OS & TL & EI & OCB & OS & TL & EI & OCB & OS \\
\hline EI & 1 & & & & $\mathbf{0 . 8 7 6}$ & & & & & & \\
\hline OCB & 0.616 & 1 & & & 0.616 & $\mathbf{0 . 7 8 7}$ & & & 0.683 & & \\
\hline OS & 0.535 & 0.612 & 1 & & 0.535 & 0.612 & $\mathbf{0 . 8 5 3}$ & & 0.584 & 0.668 & \\
\hline TL & 0.493 & 0.653 & 0.603 & 1 & 0.493 & 0.653 & 0.603 & $\mathbf{0 . 8 1 9}$ & 0.532 & 0.703 & 0.647 \\
\hline
\end{tabular}

RMStheta : 0.115; SRMR: 0.056; Chi-Square: 817,980; GoF: 0.536; NFI: 0.860

In Table 2, Heterotrait-Monotrait (HTMT) ratios are given together with Disciriminant Validity values according to Fournell-Larckrt Criterion and correlations between variables. These rates are one of the recommended values for the Discriminant Validity (Henseler et al., 2015). If HTMT ratio of 0.85 (Clark \& Watson, 1995; Kline, 2011) or 0.90 (Gold et al., 2001) is greater then Discriminant Validity is not achieved. Table 2 shows the HTMT values obtained for the model. All values in the table are less than 0.85 , which can be taken as a reference limit.

Table 2. Another result presented is the Fit Summary values. These values are Standardised Root Mean Square Residual (SRMR), Chi-Square and NFI. For the SRMR value, values below 0.08 are defined as good fit values (Hu \& Bentler, 1999), whereas the SRMR value is 0 indicates perfect fit (Hooper et al., 2008). The SRMR values for the model were calculated as 0.056 . This value is below 0.08 . The model has good compliance values of Hu and Bentler (1999). A NFI value higher than 0.90 indicates that the model is a well-matched model. However, this value was obtained as 0.86 for the study. Another alternative is the value of the goodness of harmony RMRtheta. This value works with the same logic as the SRMR value. If the RMStheta value is less than 0.12 , it can be interpreted as a good fit (Henseler et al., 2015). Tenenhaus et al. (2005) to test the validity of the model proposed GoF statistics. This statistic is found with geometric mean of the average communality and the 
average and gives results in the good ness of the model's harmony. The fact that the GoF value is greater than $0.36(\mathrm{GoF}=0.536)$ is a good indicator of compliance. The model was found to have good fit for all Fit indexes except for the NFI value. After the model is interpreted with these values and determined to be a well compatible model, hypotheses established through the model can be tested.

Table 3. Path coefficients and test results for hypotheses

\begin{tabular}{l|l|c|c|c|c}
\hline \multicolumn{1}{c|}{ Hip. } & \multicolumn{1}{c|}{ Paths } & Path Coefficients & T Statistics & P Values & Decision \\
\hline H1 & OS -> EI & 0.372 & 5.356 & 0.000 & Accept \\
\hline H2 & OS -> OCB & 0.340 & 6.097 & 0.000 & Accept \\
\hline H3 & TL -> EI & 0.270 & 3.923 & 0.000 & Accept \\
\hline H4 & TL -> OCB & 0.449 & 7.962 & 0.000 & Accept \\
\hline H5 & TL -> OS & 0.606 & 12.523 & 0.000 & Accept \\
\hline
\end{tabular}

Table 3. Path gives the results of the model. This model shows whether established relationships are supported by the model. For each hypothesis, the T statistics values of Path Coefficient values are greater than 1.96, which is the $\mathrm{T}$ table value of $95 \%$ trust level. Also, for all hypotheses, Path Coefficient values and $\mathrm{P}$ value values less than 0.05 reveal that all relationships are supported. The results are in agreement with all of the hypothesized path model relationships among the constructs. There is a positive correlation between variables.

Finally, Mediator effect between variables was tested in the model established with PLS. The results of the analysis are given in Table 4.

Table 4. Mediator Effect Results

\begin{tabular}{l|l|l|l|l|l|l|l|l|l|l}
\hline Hip. & Paths & $\begin{array}{l}\text { Cath } \\
\text { Coef. } \\
\mathbf{a})\end{array}$ & $\begin{array}{l}\text { Path } \\
\text { Coef. } \\
\mathbf{( b )}\end{array}$ & $\begin{array}{l}\text { Path } \\
\text { Coef. } \\
(\mathbf{c})\end{array}$ & $\begin{array}{c}\text { T.Ind. } \\
\text { Effect } \\
(\mathbf{a}) *(\mathbf{b})\end{array}$ & $\begin{array}{c}\text { Total } \\
\text { Effect } \\
\left(\mathbf{a}^{*} \mathbf{b}+\mathbf{c}\right)\end{array}$ & $\begin{array}{c}\mathbf{T} \\
\text { Stat. }\end{array}$ & $\begin{array}{c}\text { P } \\
\text { Values }\end{array}$ & VAF & Decision \\
\hline H6 & TL->OS ->OCB & 0.606 & 0.340 & 0.449 & 0.206 & 0.655 & 5,707 & 0,000 & 0.31 & Accept/Partial \\
\hline H7 & TL->OS->EI & 0.606 & 0.372 & 0.270 & 0.225 & 0.495 & 5,188 & 0,000 & 0.45 & Accept/Partial \\
\hline
\end{tabular}

In the last part of the application, the mediator effect of OS was investigated. Path Coef from Smart PLS 3.2. program for testing $\mathrm{H} 6$ and $\mathrm{H} 7$ hypotheses. values were used. (a) Path value between the first and second variables, and (b) Path coefficient between the second and third variables. Nitzl et al. (2016) recommended the method used in the examination of the mediator effect. In order to use this method, VAF values are calculated first. When calculating the VAF value; VAF $=a{ }^{*} b /\left(a{ }^{*} b+c\right)$ equation was used. " $c$ " is the Path Coefficient value between TL and OCB. $\left(a{ }^{*} b+c\right)$ shows the total effect value. VAF value for H6; VAF $=0.206 / 0.655=0.31$. The VAF value is used to calculate the ratio of indirect effect and total effect (Nitzl et al., 2016). If VAF values are below $20 \%$, zero mediator effect is mentioned, while VAF value between $20 \%$ and $80 \%$ is partial and more than $80 \%$ means full mediator effect (Hair et al., 2016). Table 4 . h6 and H7 hypotheses are accepted. OS has a partial mediator effect for both hypotheses.

\section{Discussion}

Employees who bear responsibility for the decisions of the transformational leaders are more motivated to propose new and advanced methods that may influence the possible consequences of these decisions (Axtell et al., 2000). Adopting a transformative leadership style, leaders have an inspiring vision; encourages employees to question the current situation and improve themselves (Pieterse et al., 2010). Besides transformational leadership, organizational support is also important. Organizational support is about how much employees are interested in their personal needs and well-being. Employees who believe they have the support of their organizations do not think that the environment they work in is threatening, but they feel supported to achieve their goals and goals. Employees do not want to achieve their goals if they believe that they do not receive support from their organizations and they face dissatisfaction (Poon et al., 2007). Organizational support also includes the psychological contract process between the employee and the 


\section{F. Sönmez Çakır - Z. Adıgüzel 12/1 (2020) 111-125}

organization or the employee and those in its lower level. Therefore, in response to the support provided by the organization and the value it attaches to employee contributions, employees are satisfied with their jobs, managers and working environment (Çakar \& Yildiz, 2009). If the participation of the employees is ensured correctly, both feedback from the employees and feedback from the employees will positively affect the activities of the organization. It is also important to note that employees' opinions should be taken into account but not to use it as a force (Newman \& Griggs, 2008). The most important task here is to lead the way in ensuring the best participation of employees. Leadership has the key role in managing and involving employees (Murrell \& Meredith, 2000). The idea that leaders who refuse the participation of employees often agree is that employees can have a say in the management of the organization by taking the power they have. For this reason, leaders' self-confidence in organizations is essential. It is also not possible to ensure employee participation if employees misuse their competencies and responsibilities. Richmond et al. (1983) said that in a study conducted, leaders should use effective communication to ensure employee participation, and that organizational support and leadership role they emphasize that it is. Organizational citizenship behavior $(\mathrm{OCB})$ is referred to as optional workplace behavior that exceeds the basic business needs of employees. These behaviors are often described as behaviors other than those that need to be done in the act. OCB has been the subject of extensive research since it was first introduced almost thirty years ago (Bateman \& Organ, 1983). According to the results of the research, rotating leadership and organizational support positively affect organizational citizenship behavior. OCB was also seen as "close and supportive" behavior that reflects the willingness of the employees who exhibited the behavior to maintain their relationship with their colleagues or the organization itself and contribute to the success of the target (Van Dyne et al., 1995). Therefore, it is possible for employees in organizations that feel the support of the organization and whose leadership style is appropriate to feel belonging to the organization and to consider themselves as one of the organization.

\section{Conclusion}

Today, the ability to continuously innovate and develop in product, service and business processes is of great importance to organizations (Janssen, 2000). For organizations, employees contribute to improving and changing the business for important factors such as improving the efficiency of the internal process and the quality of products, providing competitive advantage and ensuring long-term survival of enterprises they are increasingly hoping and needing to find them. In other words, employees need to think in-depth about their own work and proactively deal with work-related problems and challenges (Messmann, 2012). Employees' participation in the job, the needs and conditions of personal requirements and qualifications can bring the advantage of enhanced communication and assistance with colleagues and better alignment between high levels of job satisfaction (Janssen, 2000). At the same time, employees can also assume the risk of conflict and resistance from colleagues and superiors who want to avoid changes in defined work patterns and norms. There is a lot of evidence that transformational leadership and organizational citizenship behavior are workers improves organizational performance. When the literature is analyzed, there are many studies showing that there is a direct and indirect relationship between transformative leadership and OCB. Transformational leadership has a significant impact on performance (Shahhosseini et al., 2013), and extra role behavior (Nguni et al., 2006). Studies have found a positive relationship between transformative leadership and OCB (Singh \& Modassir, 2007; Eliyana, 2010; Hu et al., 2011). The transformational leader is the leader who thinks about his employees, ensures that they are open to change and innovation, does not want them to obey them without question, and wants each of them to develop and mature (Garcia-Morales et al., 2012). It sometimes addresses the transformational leader organization as a whole and sometimes individually. The transformational leader takes into account the employees' feelings and thoughts within the scope of support, shows respect, strives to meet their personal needs and behaves by considering the personal feelings of their employees (Horwitz et al., 2008; Jansen et al., 2009), as a result their participation and organizational citizenship are positively affected. Therefore, the excess of employers who behave beyond the job description is a good way to improve organizational performance. Organizational citizenship behavior enables more efficient use of resources and improves the performance of workers. In the face of high productivity and performance, administrations face fewer problems, so that managers can devote more time and energy to business strategies and to improve business processes (Ylldiz, 2016). It is thought that examining the concepts associated with the theoretical foundations of organizational citizenship behavior will contribute to the understanding of the concept. For this reason, positive (prosocial) social behavior and organizational spontaneity behavior associated with the concept of organizational citizenship will be examined. Organizational Citizenship Behaviors have been 


\section{F. Sönmez Çakır - Z. Adıgüzel 12/1 (2020) 111-125}

shown to make organizations more effective, but the participation of employees in these behaviors is not a contractual obligation, so understanding the mechanisms through which these behaviors work it is of great importance. As a result of the findings obtained as a result of the researches, the participation of employees in the work and OCB behaviors, the precursors associated with these behaviors have been identified and the results of these behaviors have been shown. The importance of leadership style and organizational support has been addressed. In future studies, especially leadership styles and organizational support need to reveal cultural differences regarding employee participation and productivity. Since the results that may arise from cultural differences may also positively affect the formation of new concepts, it should be important that future studies are within the field of examination.

\section{REFERENCES}

Addae, H. M., Boso, N., \& Ofori, D. (2017). Perceptions of absence legitimacy: Effects of job stress, organizational commitment and perceived organizational support. Pan-Pacific Journal of Business Research, 8(2), 1-19.

Akyurt, N., Alparslan, A. M., \& Oktar, Ö. F. (2015). Sağlık Çalışanlarında Liderlik Tarzları-İş Tatmini-Örgütsel Bağlllık Modeli. Süleyman Demirel Üniversitesi Vizyoner Dergisi, 6(13), 50-61.

Alarcón, D., Sánchez, J. A., \& De Olavide, U. (2015). Assessing convergent and discriminant validity in the ADHD-R IV rating scale: User-written commands for Average Variance Extracted (AVE), Composite Reliability (CR), and Heterotrait-Monotrait ratio of correlations (HTMT). In Spanish STATA Meeting (pp. 1-39).

Antoncic, B., \& Hisrich, R. D. (2001). Intrapreneurship: Construct refinement and cross-cultural validation. Journal of business venturing, 16(5), 495-527.

Apostolou, A. (2000). INNOREGIO: Dissemination of innovation and knowledge management techniques. D. of Production Engineering \& Management, Technical University of Crete. Accessed, 18(09).

Aube, C., Rousseau, V., \& Morin, E. M. (2007). Perceived organizational support and organizational commitment: The moderating effect of locus of control and work autonomy. Journal of managerial Psychology, 22(5), 479-495.

Axtell, C. M., Holman, D. J., Unsworth, K. L., Wall, T. D., Waterson, P. E., \& Harrington, E. (2000). Shopfloor innovation: Facilitating the suggestion and implementation of ideas. Journal of Occupational and Organizational Psychology, 73, 265-286.

Bagozzi, R. P., \& Yi, Y. (1988). On the evaluation of structural equation models. Journal of the Academy of Marketing Science, 16(1), 74-94.

Barbuto, J. E. (2005). Motivation and transactional, charismatic, and transformational leadership: a test of antecedents. Journal of Leadership and Organizational Studies, 11(4), 26-40.

Bass, B. M. (1990). From transactional to transformational leadership: Learning to share the vision. Organizational dynamics, 18(3), 19-31.

Bateman, T. S., \& Organ, D.W. (1983). Job Satisfaction and the Good Soldier: The relationship between affect and employee "citizenship". Academy of Management Journal, 26(4), 587-595.

Burns, J. M. (1978). Leadership. New York: Harper and Row.

Clark, L. A., \& Watson, D. (1995). Constructing validity: Basic issues in objective scale development. Psychological assessment, 7(3), 309.

Cohen, J. (2013). Statistical power analysis for the behavioral sciences. Routledge.

Cotton, J. L. (1993). Employee involvement: Methods for improving performance and work attitudes. Sage Publications, Inc.

Çakar, N. D., \& Yildiz, S. (2009). Örgütsel Adaletin İş Tatmini Üzerindeki Etkisi:" Algılanan Örgütsel Destek" Bir Ara Değişken Mi?. Elektronik Sosyal Bilimler Dergisi, 8(28), 68-90. 


\section{F. Sönmez Çakır - Z. Adıgüzel 12/1 (2020) 111-125}

Çavuş, M. F., \& Akgemci, T. (2008). İşletmelerde Personel Güçlendirmenin Örgütsel Yaratıcllık ve Yenilikçiliğe Etkisi: İmalat Sanayisinde Bir Araştırma, Selçuk Üniversitesi Sosyal Bilimler Enstitüsü Dergisi, 20, 229244.

DeConinck, J. B., \& Johnson, J. T. (2009). The effects of perceived supervisor support, perceived organizational support, and organizational justice on turnover among salespeople. Journal of Personal Selling \& Sales Management, 29(4), 333-350.

Dijkstra, T. K., \& Henseler, J. (2015). Consistent partial least squares path modeling. MIS quarterly, 39(2), 297316.

Eisenbeiss, S. A., van Knippenberg, D., \& Boerner, S. (2008). Transformational leadership and team innovation: Integrating team climate principles. Journal of applied psychology, 93(6), 1438.

Eisenberger, R., Huntington, R., Hutchison, S., \& Sowa, D. (1986). Perceived organizational support. Journal of Applied psychology, 71(3), 500.

Eliyana, A. (2010). Impacts of transactional and transformational leaderships upon organizational citizenship behavior. Journal of US-China Public Administration, 7(6), 24-30.

Erdogan, B., Kraimer, M. L., \& Liden, R. C. (2004). Work value congruence and intrinsic career success: The compensatory roles of leader-member exchange and perceived organizational support. Personnel psychology, 57(2), 305-332.

Eren, E. (1998). Örgütsel Davranıs Ve Yönetim Psikolojisi, 5. Baskı, İstanbul, Beta Yayıncılık.

Fornell, C., \& Larcker, D. F. (1981). Structural equation models with unobservable variables and measurement error: Algebra and statistics.

García-Morales, V. J., Jiménez-Barrionuevo, M. M., \& Gutiérrez-Gutiérrez, L. (2012). Transformational leadership influence on organizational performance through organizational learning and innovation. Journal of business research, 65(7), 1040-1050.

Gold, A. H., Malhotra, A., \& Segars, A. H. (2001). Knowledge management: An organizational capabilities perspective. Journal of management information systems, 18(1), 185-214.

Gürsel, M. \& Negiş, A. (2008). Liderlik ve Rolleri, Endüstri ve Örgüt Psikolojisi, Eğitim Akademi Yayınları, İstanbul.

Hair F., Hult, M., Ringle, C., \& Sarstedt, M. (2016). A primer on partial least squares structural equation modeling (PLS-SEM): Sage Publications.

Hair, J. F., Ringle, C. M., \& Sarstedt, M. (2011). PLS-SEM: Indeed a silver bullet. Journal of Marketing theory and Practice, 19(2), 139-152.

Hair, J. F., Risher, J. J., Sarstedt, M., \& Ringle, C. M. (2019). When to use and how to report the results of PLSSEM. European Business Review, 31(1), 2-24.

Hellman, C. M., Fuqua, D. R., \& Worley, J. (2006). A reliability generalization study on the survey of perceived organizational support: The effects of mean age and number of items on score reliability. Educational and Psychological Measurement, 66(4), 631-642.

Hemedoğlu, E., \& Evliyaoğlu, F. (2012). Çalışanların Dönüşümcü Liderlik Algılarının Örgütsel Bağlılıkları Üzerindeki Etkilerinin İncelenmesi. İşletme Araştırmaları Dergisi, 4(1), 58-77.

Henseler, Jö., Ringle, C. M. \& Sarstedt, M. (2015). A new criterion for assessing discriminant validity in variance-based structural equation modeling. Journal of the Academy of Marketing Science, 1-21.

Hooper, D., Coughlan, J., \& Mullen, M. (2008). Structural Equation Modelling: Guidelines for Determining Model Fit. Electronic Journal of Business Research Methods, 6(1), 53-60.

Horwitz, I. B., Horwitz, S. K., Daram, P., Brandt, M. L., Brunicardi, F. C., \& Awad, S. S. (2008). Transformational, transactional, and passive-avoidant leadership characteristics of a surgical resident 


\section{F. Sönmez Çakır - Z. Adıgüzel 12/1 (2020) 111-125}

cohort: analysis using the multifactor leadership questionnaire and implications for improving surgical education curriculums. Journal of Surgical Research, 148(1), 49-59.

Hu, J., Wang, Z., Liden, R. C., \& Sun, J. (2011). Transformational leadership and organizational citizenship behaviors: Looking at the role of both leaders' and followers' core self-evaluation. In Academy of Management Annual Meeting Proceedings (Vol. 1, pp. 1-6).

Hu, L. T., \& Bentler, P. M. (1999). Cutoff criteria for fit indexes in covariance structure analysis: Conventional criteria versus new alternatives. Structural equation modeling: a multidisciplinary journal, 6(1), 1-55.

Hulland, J. (1999). Use of partial least squares (PLS) in strategic management research: A review of four recent studies. Strategic management journal, 20(2), 195-204.

Imam, S., \& Javed, T. (2019). Job Security, Organizational Support and Employee Performance: Mediating role of Employee Satisfaction in Medical Sector of Pakistan. INTERNATIONAL JOURNAL OF ACADEMIC RESEARCH IN BUSINESS AND SOCIAL SCIENCES, 9(3).

İnce, M. (2005). Değişim Olgusu ve Örgütlerde İnsan Kaynakları Yönetiminin Değişen Fonksiyonları, Selçuk Üniversitesi Sosyal Bilimler Enstitüsü Dergisi, 14, 319-339.

Jansen, J. J., Vera, D., \& Crossan, M. (2009). Strategic leadership for exploration and exploitation: The moderating role of environmental dynamism. The Leadership Quarterly, 20(1), 5-18.

Janssen, O. (2000). Job demands, perceptions of effort-reward fairness and innovative work behaviour. Journal of Occupational and organizational psychology, 73(3), 287-302.

Johlke, M. C., Stamper, C. L., \& Shoemaker, M. E. (2002). Antecedents to boundary-spanner perceived organizational support. Journal of Managerial Psychology, 17(2), 116-128.

Jöreskog, K. G. (1970). A general method for estimating a linear structural equation system. ETS Research Bulletin Series, 1970(2), i-41.

Katz, D. (1964). The motivational basis of organizational behavior. Behavioral Science, 98(2), 131-133.

Kline, R. B. (2011). Principles and practice of structural equation modeling (4 th editions). New York.

Kock, N., \& Hadaya, P. (2018). Minimum sample size estimation in PLS-SEM: The inverse square root and gamma-exponential methods. Information Systems Journal, 28(1), 227-261.

Li, N., Chiaburu, D. S., Kirkman, B. L., \& Xie, Z. (2013). Spotlight on the followers: An examination of moderators of relationships between transformational leadership and subordinates' citizenship and taking charge. Personnel Psychology, 66(1), 225-260.

Locke, E. A., \& Schweiger, D. M. (1979). Participation in decision-making: One more look. Research in organizational behavior, $1(10), 265-339$.

London, M. (1988). Organizational support for employees' career motivation: A guide to human resource strategies in changing business conditions. People and Strategy, 11(1), 23.

Marchington, M., \& Wilkinson, A. (2005). Direct participation and involvement. Managing human resources: personnel management in transition, 398-423.

Messmann, G. (2012). Innovative work behaviour: Investigating the nature and facilitation of vocational teachers 'contributions to innovation development (Doctoral dissertation).

Moorman, R. H. (1991). Relationship between organizational justice and organizational citizenship behaviors: Do fairness perceptions influence employee citizenship?. Journal of applied psychology, 76(6), 845.

Murrell, K. L., \& Meredith, M. (2000). Empowering employees. McGraw Hill Professional.

Nam, S. W. (2003). Employees in Asian enterprises: Their potential role in corporate governance.

Neter, J., Kutner, M. H., Nachtsheim, C. J., \& Wasserman, W. (1996). Applied linear statistical models (Vol. 4, p. 318). Chicago: Irwin. 


\section{F. Sönmez Çakır - Z. Adıgüzel 12/1 (2020) 111-125}

Newman, J., \& Griggs, D. (2008). Productivity affected by the way teams handle conflict. The Vancouver Sun $\mathrm{F}, 6$.

Nguni, S., Sleegers, P., \& Denessen, E. (2006). Transformational and transactional leadership effects on teachers' job satisfaction, organizational commitment, and organizational citizenship behavior in primary schools: The Tanzanian case. School effectiveness and school improvement, 17(2), 145-177.

Nitzl, C., Roldan, J. L., \& Cepeda, G. (2016). Mediation analysis in partial least squares path modeling: Helping researchers discuss more sophisticated models. Industrial management \& data systems, 116(9), 18491864.

Nunnally, J. (1978). Psychometric theory. New York: McGraw-Hill.

Organ, D. W. (1988). Organizational citizenship behavior: The good soldier syndrome. Lexington, MA: Lexington.

Osterman, P. (2000). Work reorganization in an era of restructuring: Trends in diffusion and effects on employee welfare. ILR Review, 53(2), 179-196.

Öğüt, A., Akgemci, T., \& Demirsel, M. T. (2004). Stratejik İnsan Kaynakları Yonetimi Bağlamında Örgütlerde İsgören Motivasyonu Süreci, Selçuk Üniversitesi Sosyal Bilimler Enstitüsü Dergisi, 12, 277-290.

Pieterse N. A., van Knippenberg, D., Schippers, M., \& Stam, D. (2010). Transformational and transactional leadership and innovative behavior: The moderating role of psychological empowerment. Journal of Organizational Behavior, 31(4), 609-623.

Podsakoff, P. M., Bommer, W. H., Podsakoff, N. P., \& MacKenzie, S. B. (2006). Relationships between leader reward and punishment behavior and subordinate attitudes, perceptions, and behaviors: A metaanalytic review of existing and new research. Organizational Behavior and Human Decision Processes, 99(2), 113-142.

Podsakoff, P. M., MacKenzie, S. B., Moorman, R. H., \& Fetter, R. (1990). Transformational leader behaviors and their effects on followers' trust in leader, satisfaction, and organizational citizenship behaviors. The leadership quarterly, 1(2), 107-142.

Poon, J. M., Mohd Salleh, A. H., \& Senik, Z. C. (2007). Propensity to trust as a moderator of the relationship between perceived organizational support and job satisfaction. International Journal of Organization Theory \& Behavior, 10(3), 350-366.

Rangus, K., \& Slavec, A. (2017). The interplay of decentralization, employee involvement and absorptive capacity on firms' innovation and business performance. Technological Forecasting and Social Change, 120, 195-203.

Rangus, K., Drnovšek, M., \& Di Minin, A. (2016). Proclivity for open innovation: Construct development and empirical validation. Innovation, 18(2), 191-211.

Richmond, V. P., Wagner, J. P., \& McCroskey, J. C. (1983). The impact of perceptions of leadership style, use of power, and conflict management style on organizational outcomes. Communication Quarterly, $31(1), 27-36$.

Ringle, C. M., Sarstedt, M., Mitchell, R., \& Gudergan, S. P. (2018). Partial least squares structural equation modeling in HRM research. The International Journal of Human Resource Management, 1-27.

Shahhosseini, M., Silong, A. D., \& Ismaill, I. A. (2013). Relationship between transactional, transformational leadership styles, emotional intelligence and job performance. Researchers World, 4(1), 15.

Shamir, B., \& Howell, J. M. (1999). Organizational and contextual influences on the emergence and effectiveness of charismatic leadership. Leadership Quarterly, 10(2), 257-283.

Sharma, P. N., Shmueli, G., Sarstedt, M., Danks, N., \& Ray, S. (2019). Prediction-oriented model selection in partial least squares path modeling. Decision Sciences. 


\section{F. Sönmez Çakır - Z. Adıgüzel 12/1 (2020) 111-125}

Singh, T., \& Modassir, A. (2007). Relationship of emotional intelligence with transformational leadership and organizational citizenship behavior. IIM Bangalore Research Paper, (262).

Tenenhaus, M., Vinzi, V. E., Chatelin, Y. M., \& Lauro, C. (2005). PLS path modeling. Computational statistics $\&$ data analysis, 48(1), 159-205.

Thomas, J. R., Nelson, J. K., \& Silverman, S. J. (2015). Research methods in physical activity. Human kinetics.

Torun, Z.K. (2010). Bir Performans İyileştirme Faktörü Olarak Örgütsel Vatandaşlık., http://www.mufettisler.net/yazarlar/42-zeki-kursat-torun/313-bir-performansiyilestirmefaktoruolarak. html (25.05.2011).

Tucker, B. A., \& Russell, R. F. (2004). The influence of the transformational leader. Journal of Leadership \& Organizational Studies, 10(4), 103-111.

Van Dyne, L., Cummings, L. L., \& McLean Parks, J. M (1995). Extra-role behaviors : In pursuit of construct and definitional clarity (A bridge over muddied waters). In L. L. Cummings and B. M.Staw (Eds.), Research in Organizational Behavior (Vol.17,pp. 215-285). Greenwich, CT: JAI Press.

Wagner III, J. A. (1994). Participation's effects on performance and satisfaction: A reconsideration of research evidence. Academy of management Review, 19(2), 312-330.

Wang, P., Rode, J. C., Shi, K., Luo, Z., \& Chen, W. (2013). A workgroup climate perspective on the relationships among transformational leadership, workgroup diversity, and employee creativity. Group \& Organization Management, 38(3), 334-360.

Washington, R. R. (2007). Empirical relationships among servant, transformational and transactional leadership: similarities, differences and correlations with job satisfaction and organizational commitment. The Degree of Doctor of Philosophy. Auburn University, Alabama.

Wold, H. (1975). Path models with latent variables: The NIPALS approach. In Quantitative sociology (pp. 307357). Academic Press.

Wong, K. K. K. (2019). Mastering partial least squares structural equation modeling (PLS-SEM) with Smartpls in 38 hours. iUniverse.

Yang, W. H. (2010). Relationships among internal marketing perceptions, organizational support, job satisfaction and role behavior in healthcare organizations. International Journal of Management, 27(2), 235.

Yavuz, E. (2009). İşgörenlerin Dönüşümcü Liderlik ve Örgütsel Bağlilik İle İlgili Tutumlarina Yönelik Bir Araştirma. İşletme Araştırmaları Dergisi, (2), 51-69.

Yazıcıoğlu, Y., \& Erdoğan, S. (2004). SPSS applied scientific research methods. Ankara: Detay Publishing.

Yıldız, M. S. (2016). İşyerinde Mobbing Davranışlarının Spor ve Fiziksel Etkinlik İşletmeleri Çalışanlarının Örgütsel Vatandaşlık Davranışına Etkisi. Dokuz Eylül Üniversitesi Sosyal Bilimler Enstitüsü Dergisi, 18(1), 165-180. 